revista ANTHROPOLÓGICAS

Ano 21, 28(2): 85-111, 2017

\title{
'Se Fantasiar de Índio é Fácil, Ser Índio é Difícil, Tem que Estudar Muito’: vivências indígenas na cidade do Rio de Janeiro
}

Camila Bevilaqua $^{a}$

O artigo lida com a experiência de indígenas na cidade, situações de discriminação sofridas por esses e a maneira como pensam a sua indianidade no ambiente urbano. Partindo de dados etnográficos da experiência de três indígenas de diferentes povos, habitantes da cidade do Rio de Janeiro, são discutidas como esses refletem sobre o preconceito e o movimento indígena urbano, buscando relacionar esses com as recentes teorias da contramestiçagem.

Indígenas na Cidade; Mestiçagem; Educação Indígena; Rio de Janeiro Indígena; Aldeia Vertical.

"Enquanto as maneiras de ser ou de agir de certos homens forem problemas para outros homens, haverá lugar para uma reflexão sobre essas diferenças que, de forma sempre renovada, continuarão a ser o domínio da antropologia".

Claude Lévi-Strauss.

presente artigo se baseia em um trabalho de campo conduzido ao longo do ano de 2016 em um local chamado de Aldeia Vertical, no Rio de Janeiro. A Aldeia Vertical consiste em um prédio do programa

a Doutoranda em Antropologia Social pelo Museu Nacional (UFRJ). Email: mila. bevi@gmail.com. 
gonvernamental Minha Casa, Minha Vida, onde residem exclusivamente indígenas de diferentes povos. São pessoas que antes habitavam a Aldeia Maracanã, que teve sua desocupação forçada em $2013^{1}$. Durante minha pesquisa, me aproximei de três moradores do prédio, Dauá Puri, Niara do Sol e Iracema Pankararu. Os três participavam de uma horta comunitária no Complexo do São Carlos, que buscavam construir como um espaço privilegiado de 'divulgação da cultura indígena’ através do envolvimento com as plantas e a prática, onde se deu a maioria da nossa convivência.

Busco apresentar aqui, os frutos da minha interlocução com essas pessoas, seus trajetos, movimentos pela cidade e conversas que tivemos. Enfoco aqui o tema do preconceito, central para sua experiência enquanto indígenas em um grande centro urbano. São essenciais as suas experiências e formulações sobre sua indianidade e as percepções externas dessas. É colocado em foco as diferentes elaborações, não só sobre o que é ser índio, mas também o que é se tornar, voltar a ser, deixar de ser índio. É possível ver como de maneira intricada a indianidade é, assim, elaborada mais como um movimento em uma certa direção, do que uma qualidade inata, apesar da existência de um foco na ascendência indígena. $\mathrm{O}$ 'sangue indígena' é uma substância complexa, que por si só não garante uma identificação, sendo preciso ser acompanhado da incorporação de uma cultura que é entendida enquanto estudo.

Além dos encontros com os não-indígenas, surgem também diversas questões internas ao movimento indígena urbano, que é desenhado aqui como uma rede complexa relatada do ponto de vista específico meus interlocutores. Relato aqui algumas situações e conversas relevantes sobre o tema como presenciei e foram relatados por eles. Aponto também para o papel que o humor desempenha na mediação dessas relações, principalmente em situações de discriminação. Por final, relaciono os temas delineados as novas proposições da teoria da contramestiçagem (Goldman 2015a), buscando mostrar como a maneira de pensar a identidade e a mistura, nesse caso, fogem as teorias clássicas da mestiçagem. 


\section{Feira indígena}

No dia 19 de abril, acompanhei Niara até a $1^{a}$ Feira Indígena de Niterói. A feira começou às oito horas da manhã e durou até às oito horas da noite. Muitos moradores da Aldeia Vertical estavam lá e outras pessoas de fora também. Pareciam todas se conhecer. Vendiam principalmente artesanato, com exceção de duas barracas de comida (tapioca e caldo de peixe) e a de Dauá que oferecia informações e panfletos sobre os Puri - grupo da zona da mata mineira considerado extinto que hoje vive um movimento de ressurgência. Parece existir um circuito de eventos indígenas no Rio de Janeiro, onde todos se conhecem e corre muita fofoca. Isso inclui eventos culturais de todos os tipos: feiras de artesanato, contação de história, pintura corporal, eventos de cura e xamanismo. Niara montou uma barraca de fazer tapioca ao lado da barraca de artesanato de Iracema. Eu fui como ajudante, apesar de não saber fazer nada.

O problema ocorreu quando chegamos, pois a organização do evento não tinha disponibilizado uma fonte de energia ainda, então Niara não podia ligar a sua chapa para fazer as tapiocas. Isso gerou um certo aborrecimento, e depois de montar tudo na barraca, sem poder fazer nada, sentamos à sombra e ficamos conversando.

Quase já no fim da manhã, chegou uma mulher da produção do evento. Ela era branca, muito arrumada e muito apressada. De longe de onde estava sentada, a vi abordar Iracema para perguntar se essa precisaria de uma fonte de energia. Iracema começou a responder dizendo que não, mas que tinha uma colega que precisava e, ao fazer isso, se virou enquanto falava procurando localizar Niara. A produtora, rudemente, interrompeu Iracema e mandou que ela olhasse na sua direção ao falar, senão ela não conseguiria entender nada. Iracema pausou. Olhando para a produtora, repetiu o que tinha falado. Apontou para Niara, que então já estava sentada em uma cadeira de plástico ao meu lado. A mulher foi até nós e informou Niara, com a mesma falta de cortesia de antes, que se ela quisesse usar uma fonte de 
energia, teria de se mudar para as barracas que estavam no início da feira (sob o sol, diga-se de passagem). Niara disse que não iria. Disse, inclusive, e com calma, que iria embora assim que seu amigo (Dauá) chegasse. A mulher ficou sem reação e pediu, com um pouco mais de cuidado, que Niara ficasse e mudasse de local. Niara disse à mulher que era um absurdo que ela se chamasse de produtora estando aquela feira tão mal organizada. Ela mesma já havia organizado muitos eventos na vida e sabia como fazer esse tipo de coisa. Disse que estava ali desde cedo, com comida que estragava e podia processá-la. Que iria processá-la e chamar a mídia, chamar a atenção para o fato de que era idosa. E índia. Completou dizendo que a mulher era uma petulante. A mulher, então um pouco abalada, se sentou na cadeira vaga ao lado de Niara e mudou completamente o tom de voz. Pediu encarecidamente que Niara ficasse. Niara não cedeu e continuou provocando a mulher. Mencionou que era a coordenadora da Horta Comunitária do São Carlos. A produtora à essa altura já estava chorando e apelou para a situação política do país. Disse que todos estavam com o ânimo exaltado e que, ainda por cima, seu carro havia quebrado no meio do túnel naquela manhã. Niara não se impressionou muito com o sofrimento da mulher, mas sobre a situação política do país, começou a contar uma história sobre uma reunião de pajés de todo o país, na qual ela estava presente.

Nessa reunião, foi sugerido que eles envenenassem todos os políticos para acabar com a corrupção, uma vez que eles teriam, com seus conhecimentos, o meio de fazer isso. A sugestão, no entanto, foi descartada. A entrada dos brancos nas terras brasileiras seria culpa dos índios. Esses, obviamente, como me disse, teriam como ter impedido a invasão dos portugueses, se quisessem. Não o fizeram por curiosidade e ingenuidade e agora deviam pagar por isso. Já havia inclusive à época mitos que previam a chegada dos homens estranhos barbados em caravelas e recomendavam que eles fossem recusados. Os avisos ignorados, agora restava penar nas mãos dos descendentes dos homens das caravelas. 
A produtora ouviu muito impressionada, só parando de olhar para Niara para ordenar (novamente de maneira grosseira) que um menino que trabalhava no evento desse um jeito de colocar a fiação necessária para que Niara pudesse ficar onde já estava.

Depois Niara me disse que o problema dessas pessoas é que "elas acham que estão te fazendo um favor ao te convidar para um evento". Essa foi uma reclamação que ouvi algumas vezes. A ideia de que o índio deveria ficar honrado de ter um espaço, por menor e mais mal organizado que seja, para mostrar seu trabalho, divulgar sua cultura. Ouvi algumas pessoas do prédio reclamarem disso. Para falar em escolas, evento aparentemente recorrente, eles não vão de graça, mas pedem um cachê, ou alternativamente um lugar para vender seu artesanato, e que cada criança leve um quilo de alimento não perecível (que eles escolhem, senão, me falaram, todo mundo leva fubá, porque acha que é do que o índio gosta).

Aconteceu que, com a demora para armar a barraca, eu tive a chance de conversar muito com Niara. Ela disse esse dia que seria mais índia do que muitos dos Fulni-ô que vivem na aldeia, porque a alimentação deles agora já está muito branca. Eles agora só comem feijão e arroz, que não é a comida típica, e não sabem preparar peixe na folha da bananeira e macaxeira como ela. Além disso, eles não conhecem várias outras práticas, como o lugar e a hora certa para pitar o cachimbo, o que ela aprendeu com o pai e o avô. Além de ressaltar o papel da alimentação, responsável por 'deixar o sangue forte', Niara inverte uma lógica que parece às vezes existir tanto no senso comum quanto em alguns lugares do movimento indígena: de que os índios que vivem em cidade seriam menos indígenas, dentro de um gradiente de indianidade, do que aqueles que vivem em aldeias. A identidade nunca é negada completamente, mas os índios urbanos são indicados muitas vezes como uma versão mais fraca daqueles na aldeia.

O ambiente urbano abre espaço para a inclusão dentro do movimento indígena de pessoas com trajetórias diversas, como de resgate ou de redescobrimento. Inicialmente, eu não havia percebido isso e 
partia de uma premissa de que todos aqueles índios tinham saído da aldeia e que o que eu deveria fazer era tentar entender como eles tinham chegado até a cidade. Fui então durante a feira a algumas outras barraquinhas conversar com outras pessoas para tentar descobrir suas trajetórias. Esse movimento se revelou muito mais complicado do que eu imaginava. Depois de pouco tempo, Niara me chamou de volta. Outras pessoas que sabiam que eu tinha ido até a feira com ela haviam-lhe avisado o que eu estava fazendo e dito que eu era muito ingênua e podia "cair na conversa" de pessoas perigosas ali. Ela me explicou que eu deveria ter cuidado com o homem com quem eu estava conversando na hora em que ela me chamou. Ele havia se apresentado para mim como um Tupi. Eu estava fazendo perguntas tentando entender quem ele era exatamente. Principalmente, eu estava perguntando quem eram seus pais, onde ele tinha nascido e como ele tinha aprendido a língua. Ele me respondia feliz e já estava falando sobre como ele tinha um 'dom' de cura. Niara me disse que, se eu "entrasse no papo" dele, dali a pouco ele estaria se oferecendo a me tratar e me convencendo a participar de rituais de pajelança dirigidos por ele.

Depois desse dia, ouvi muito sobre os perigos de fazer rituais na cidade com alguém que não seja de confiança e muitas de histórias de casos que haviam dado errado. O problema, me explicaram, é que na cidade muitos índios se apresentam como pajés ou xamãs, posição que eles não poderiam ocupar em suas aldeias, que têm regras mais estritas para o exercício dessa função. Na cidade, eles têm acesso a um público que muitas vezes tem uma visão estereotipada dos índios e acredita que todos eles estão autorizados a realizar certas cerimônias ou "acha que são todos espiritualizados e esquece que índio é humano também”, como me falaram criticamente.

Sobre o caso desse pajé, eu ouvi ainda muitas outras histórias e o reencontrei em outros eventos durante o meu trabalho de campo. Eu questionei quem seriam as pessoas que se tratam com ele, que poderiam não saber que ele não tem capacidade de fazer aquilo a que se propõe. Responderam-me que as pessoas na cidade não querem tra- 
tamentos sérios muitas vezes, porque esses dão mais trabalho. Muitos brancos preferem o caminho mais fácil e rápido e caem na 'conversa fiada'. Querem pegar atalhos, não respeitando que a cultura indígena é complexa ${ }^{2}$. Como Niara disse ela é como a nossa educação: tem muitas partes, e não se deve tentar pular etapas. Sempre ressaltaram que o que esse homem que se apresentava como pajé fazia era muito grave. Por não ser de uma família de pajés, ele não poderia estar mexendo com as energias com que estava. Falando-me sobre isso, Iracema disse: "Como é que eu vou fazer uma coisa que eu não sei o que eu tô fazendo?”. A questão é justamente aquela do aprendizado. Ele não aprendeu a ser pajé porque não é de família de pajés. Esse não foi um conhecimento que foi passado para ele, não é uma habilidade que ele tenha. Perguntei se havia uma chance de ele nem ser índio. Niara me respondeu que ele podia até ser descendente, "mas não ao ponto de tá fazendo o que ele tá fazendo".

O caso do pajé não foi o único curioso do dia. Depois de ter sido chamada à atenção, passei a circular entre as pessoas que eu já conhecia da Aldeia Vertical, perguntando para elas sobre os outros. Isso iniciou uma rede de explicações muito complexa e por vezes contendo informações contraditórias. Durante essas explicações, eu percebi uma tendência. Existiam muitas explicações sobre as trajetórias das pessoas até entrar no movimento indígena. Mas eu nunca vi, durante todo o meu trabalho de campo, alguém fazer uma afirmação categórica de que outra pessoa não era índia. Existiam, no entanto, várias maneiras de qualificar a indianidade. Dizer que a pessoa apareceu no movimento indígena de um jeito esquisito, mudou de etnia, que ela tinha parentes índios, mas já estava muito branca, etc. Dizer que alguém não é índio, definitivamente, era sempre algo difícil, uma vez que não se conhecia a linha de descendência da pessoa.

O homem que se apresentava como pajé havia chegado um dia à Aldeia Maracanã e não havia se apresentado como índio. Depois de um tempo, ele teria ido a uma aldeia guarani, onde aprendeu a língua, e voltou se apresentando como índio. Não só como índio, mas como 
pajé e detentor de um dom. Niara me contou tudo isso com um ar de desconfiança, que parecia indicar reprovação. Eu entendi aquilo como uma acusação de farsa. Mais tarde naquele mesmo dia, eu perguntei sobre outra pessoa da feira. Niara me contou uma história muito parecida. Essa outra pessoa havia chegado à Aldeia Maracanã um dia, ainda não índia. Depois se envolveu com um indígena, foi para uma aldeia e voltou se apresentando como índia. Dessa vez, Niara contou a história com um tom de normalidade e expressava aprovação quanto a essa pessoa. Os dois casos me deixaram um pouco confusa. Pareciame que as histórias eram similares e, enquanto uma pessoa era tratada com desconfiança, a outra parecia ser mais aceita. Só depois de muito tempo, ouvindo outros casos similares, fui entender essa lógica.

\section{Virar índio}

O movimento que ficou conhecido como Aldeia Maracanã, antes de muitas dissensões que se seguiram, começou com o intuito de encontrar os parentes perdidos na cidade: encontrar os índios que podiam estar por aqui dispersos e juntá-los em um movimento. Teria também a finalidade de lembrar algumas pessoas de que elas são ou pelo menos poderiam ser índias. Essas são as pessoas que têm parentes índios em algum nível. Elas poderiam, se quisessem, se considerar também como indígenas. Por conta de preconceito e diversas outras situações, muitas vezes essa identificação com o lado indígena é renegada. O que o movimento da Aldeia Maracanã buscava fazer era apresentar o índio como uma possibilidade atraente de ser. $\mathrm{O}$ movimento assim foi criado para resgatar os índios da cidade, e eu cheguei a ouvir reclamações sobre os índios da aldeia que agora chegavam "querendo mandar em tudo".

Em um parecer feito sobre um trâmite jurídico quanto à homologação da Terra Indígena Maró no Estado do Pará, que estava sendo justamente negada por ter sido colocada em dúvida a veracidade da indianidade dos seus impetrantes, Eduardo Viveiros de Castro escreveu o seguinte: "Continuidade histórica não é identidade imóvel, tra- 
dição não é clonagem, indianidade não é genética, e mistura cultural não invalida o direito à escolha de referências culturais privilegiadas" (Viveiros de Castro 2014:6).

No texto, o autor defende o direito de populações a buscar recuperar suas origens indígenas, demonstrando que isso não é de modo algum um embuste ou um movimento ilegítimo. Os indígenas que buscam a demarcação da sua terra são acusados de ter sofrido influência ideológica de ONGs e antropólogos que os teriam convencido a se tornar índios, quando até então esses não se identificavam como tal. Viveiros de Castro argumenta que influência ideológica não é aquela que convence os índios a reclamar sua identidade agora, mas sim aquela que outrora os convenceu a negá-la. O que essas populações fazem é só tentar recuperar o que lhes foi (violentamente) reprimido anteriormente. Ele fala contra a ideia de que a consciência da identidade tem de surgir de forma orgânica, uma vez que essa só é possível perante o contato com a sociedade externa e suas categorias. Assim, como é possível escolher essas referências culturais, o que o movimento da Aldeia Maracanã pretendia era tornar o ser índio uma escolha possivel e interessante.

Niara sempre deu a seguinte explicação: se você tiver um índio na sua linha de ascendência, até cinco gerações para trás, você também é índio. Seria o caso de assim lembrar as pessoas na cidade que tivessem um avô indígena, por exemplo, que elas também poderiam se ver como indígenas. Ou pelo menos como tendo um elemento indígena que não se dissolve na cultura branca, que pode ser também usado, sem eliminar outras possibilidades. A estratégia para tal empreitada era divulgar a cultura indígena, apresentar comidas, cantos, rituais; chamar a atenção para aspectos positivos em geral dos modos de vida indigenas.

$\mathrm{Na}$ Aldeia Verical, se referiam a uma diferença entre índios aldeados e desaldeados. Aqueles que mesmo morando na cidade, tinham uma aldeia de origem para onde poderiam voltar, eram considerados aldeados. Apontando para essa relação entre aldeados e desaldeados, 
costumavam a falar do preconceito que existe entre os próprios indígenas em relação aos índios que estão na cidade, que seriam considerados menos indígenas do que os aldeados. Iracema, por sua vez, tinha um namorado branco, e contavam de ter passado dificuldades para que ele fosse aceito como seu companheiro. Ao falar sobre isso, expunham a lógica da ascendência indígena de cinco gerações:

Iracema: Rafael sofreu o pão que o diabo amassou pra casar comigo e morar com eles. Foi muito humilhado.

Eu: Mas aí já não era índio de aldeia, era índio de cidade.

Niara: Mas pra eles não interessa.

Iracema: Rafael não é índio.

Niara: Mas ele é descendente.

Iracema: Mas ele é descendente de índio.

Niara: Então, até a quinta geração, é considerado que é. Pelas leis. Eu: Pra todas as etnias?

Niara: Lógico, menina. É uma coisa mundial. Se você é neta de alemão, bisneta de alemão. Por exemplo, japonês. Quem nasce no Japão é japonês. Quem nasce no Brasil e é filho de japonês é sansei. É nisei. Aí quem vem, vai nascendo, vai tendo outros nomes. Eu: Então suas filhas são índias?

Niara: São. Até porque o pai é descendente. E quando é a mãe que é índia, aí é mais forte.

Iracema: As minhas são, mas ninguém considera, nem elas mesmo.

Meses depois da feira, Niara me falava sobre uma pessoa que, assim como no caso do homem que se apresentava como pajé, era considerada polêmica dentro do movimento indígena. Niara, como muitos outros, reprovava muitas atitudes dessa pessoa e explicou que ela já havia dito que era de duas etnias diferentes, não sendo de nenhuma delas realmente. Eu perguntei se ela então não poderia nem mesmo ser índia. Ela, que até então estava falando de maneira revoltada sobre a pessoa, mudou de tom e disse com calma que não dava para saber, talvez ela fosse. Como sempre, não havia como aferir com certeza. Como eu parecia confusa, ela me explicou com uma comparação. Falou de Dauá. Dauá começou um processo de retomada das suas origens Puris. Ele há vinte anos diz que é Puri, pesquisa sobre isso 
e 'trabalha para a cultura'. O que diferencia Dauá do índio polêmico é a coerência e a consistência. E assim como sobre o caso da pessoa que Niara indicou como mestiça, é preciso haver uma pesquisa sobre o assunto.

Niara disse uma vez: "Se fantasiar de índio é fácil, ser índio é difícil. Tem que estudar muito". A cultura, na maneira como eles se referem, aparece constantemente como uma questão de estudo e de aprendizado. Ser índio implica um certo conhecimento. Esse conhecimento não é único, mas muito diverso; no entanto, ele tem de partir de um interesse e um aprendizado sobre o assunto. Esse conhecimento pode vir através da família e dos parentes indígenas, como no caso de Niara, ou, como no caso de Dauá, e de outros Puris, através de estudos para uma recuperação de algo que era considerado perdido.

\section{Parentes perdidos na cidade}

O movimento de encontrar os índios na cidade atrai assim muitas pessoas que buscam 'reencontrar suas origens'. A retomada se dá no sentido não de uma recuperação de uma identidade fixa que teria sido perdida, mas de um processo, de um devir. Isso pode ser feito de várias maneiras e é aí que está a diferença entre o pajé falcatrua e a outra índia da feira. Como entendi depois, parecia haver uma potencialidade indígena em todos, porém, esta deveria ser acessada da maneira correta.

O estudo é importante para aqueles que participam do movimento indígena, fazendo resgates, mas também para aqueles que querem lidar com índios. Niara tem fama de ter uma personalidade forte. Além da cena que eu presenciei na feira, em que ela fez a organizadora do evento chorar, Iracema e Dauá contaram de um outro caso que achavam muito engraçado envolvendo uma representante da Prefeitura.

Niara: Quem tem direito a reclamar é nós, que já távamos aqui... Eu vou falar tudo que quiser falar aqui. Ela não sabia nada do assunto. Aí ela começou a pesquisar e estudar, pra ninguém fazer mais isso com ela. Eu falei 'Tu é uma ignorante, não entende nada 
de índio. Tu é ignorante. Tu é burra'. E hoje é minha amiga. Não pode me ver, que me abraça. Porque com essa coisa que eu fiz com ela, ela foi obrigada a estudar sobre a cultura indígena. Eu disse 'índio não é tudo igual não, assim como você sabe que negro também não'. Que foi trazido um pouco de uma tribo, um pouco de outra. Negro é índio africano. E nem eles mesmo sabem disso. Porque não procura suas raízes. Tem que procurar, tem que pesquisar suas raízes.

A referida representante da Prefeitura, que estava na Aldeia Vertical a trabalho, foi chamada à atenção sob a alegação de que "índio não é tudo igual" e de que ela deveria se informar sobre o assunto. Isso seria fruto de um desconhecimento geral dos brasileiros sobre uma parte importante não da sua história, o que colocaria o índio só no passado, mas da sua sociedade presente. Existem muitas comunidades indígenas diversas no Brasil, que têm seu próprio modo de vida, técnicas, conhecimentos, mitos etc. Mesmo quando o índio aparece na TV, eles reclamam que essa diversidade é reduzida a estereótipos exotizantes. $\mathrm{O}$ projeto de divulgação da cultura indígena buscava corrigir isso e levar o tema para o interesse de mais pessoas.

A afirmação de que 'negro é índio africano' também era frequente. Segundo Niara, os povos nativos foram os primeiros de todo mundo. Também sobre esses, recairia o imperativo do estudo sobre os antepassados e o reconhecimento da diversidade dentre um grupo que não deveria ser visto como homogêneo.

O movimento indígena urbano parecia ter, nessa perspectiva, como uma das suas facetas, a intenção de se apresentar como uma alternativa ao que seria o modo de vida ao estilo de vista branco e citadino. Todo o seu esforço é de mostrar como o índio é uma possibilidade atual, e não algo que existe só no passado e em aberturas de Olimpíadas à la Gilberto Freyre, mostrando as contribuições de cada raça para o desenvolvimento do país. Eles apresentam essa possibilidade (virtualidade) indígena como algo vivo e que pode ser acessado (atualizado). É possível aprender muita coisa ainda, é possível pesquisar na 
história familiar se a pessoa não tem parentes indígenas longínquos e, no constante processo de transformação em que tanto os indivíduos quanto os grupos sociais sempre estão envolvidos, buscar uma direção mais indígena. Essa é uma alternativa de direção. É um virar índio no sentido de se voltar para um caminho indígena. Como um giro do eixo que se vira para uma nova direção. É um enxergar o índio como hipótese, como possibilidade, e se voltar para esse lado.

Esse sentido etimológico da palavra 'virar' foi levantado por Marcio Goldman. Algumas das definições do dicionário para o verbo são:

1. transitivo direto e intransitivo e pronominal: Mudar(-se) se de posição;

2. transitivo indireto, direto e pronominal: Tomar o rumo de;

3. transitivo indireto e pronominal: Voltar(-se) para determinada direção;

4. transitivo direto, intransitivo e pronominal: Mover em círculo;

5. transitivo direto, intransitivo e pronominal: (linguagem figurada) Passar a ter outra opinião, outro time, outro partido etc.;

6. transitivo direto: Revirar um lugar em busca de;

7. intransitivo: Passar por alteração;

8. transitivo direto: Causar ou sofrer alteração;

9. pronominal: Virar o corpo ou parte dele para determinada direção.

fato de existir essa possibilidade, de virar índio, que é incentivada pelo movimento, não significa um 'vale tudo'. Niara traça uma comparação entre a cultura indígena e a escola dos brancos. Segundo ela, existem muitas coisas a ser aprendidas e isso deve ser feito escutando aqueles que sabem, de maneira paulatina e ordenada, sem pular etapas. A diferença indígena para a escola é principalmente na ênfase na prática dos conhecimentos, e não somente no seu apreendimento abstrato. Nesse sentido, a horta comunitária que Niara lidera é considerada um espaço importante por permitir um engajamento com os corpos, através do trabalho e dos alimentos. A relação do conhecimento com a prática é comum na cosmologia transformacional dos povos amazônicos, "não é suficiente adquirir conhecimentos por meio de alianças com seres 'outros', é preciso os praticar" (Belaunde 2013:158). 


\section{Preconceito}

Um dia na horta comunitária, uma senhora moradora do São Carlos entrou no terreno. Ela queria pegar um pouco de terra para colocar nos vasos de planta da sua casa e levava um saco de plástico e uma pá. Começou a puxar conversa. Nesse dia, estávamos na horta eu, Niara, Iracema e o namorado de Iracema. Depois de um tempo conversando, ela reparou e falou em voz alta que Niara e Iracema pareciam índias. Elas confirmaram. Ela então lhes desejou boas vindas e perguntou se eram todos do Amazonas, que segundo ela é "onde tem lugar que tem índio". Todos responderam que em todo lugar do Brasil tem índio, inclusive no Rio de Janeiro, e enumeraram as aldeias do Estado.

Esse é o tipo de situação que costuma irritá-los. Na cidade, a ideia é que, quando reconhecidos, eles são vistos como pessoas deslocadas, sempre vindo de outro lugar do país. Muitas vezes a referência de indígena é aquela do índio na Amazônia. Eles reclamavam do fato de essa ser a imagem de índio da Rede Globo. Aquele que tem cabelo liso preto e anda com pouca roupa. Eles sempre repetiam para mim que essa imagem é falsa, porque apesar de existirem índios assim, existem também muitos diferentes. "Índio não tem cara", eles sempre me falavam, "pode ser de todo jeito".

Algumas vezes sua própria identidade era colocada em questão. Iracema descreveu irritada um dia em que participou de uma feira de artesanato afro, e uma mulher perguntou se ela era índia de verdade. Ela respondeu perguntando se a mulher era negra de verdade. A mulher ficou sem graça com a pergunta, mas Iracema explicou que ela não tem paciência para esse tipo de pergunta, que ela só tolera se vier de uma criança. A mulher, ela disse, não tinha que provar nada e já sabia que era negra pela cor da pele. Já ela teria que fazer algo como um teste de DNA e, assim, tirar seu sangue para provar que é índia. Disse que na cidade isso acontece com mais frequência, porque as pessoas acham que só tem índio em aldeia. Disse que é ainda pior se o índio usa celular, pois nesse caso existe mais preconceito, como se o 
uso daquela tecnologia implicasse a prova de uma falsa identidade ou de uma perda cultural.

Esse tipo de resposta expressa um uso do humor que desloca a estabilidade das posições entre os interlocutores, ao exigir colocarse na situação do outro. Lagrou (2007) sugere que esse tipo de uso do humor é característico da cosmologia transformacional indígena, onde a possibilidade de imitar o outro e de ver-se do ponto de vista do outro são instrumentais para navegar as hierarquias de poder. $\mathrm{O}$ humor, nesses casos, permite fazer uma crítica social sem engajar em uma discussão aberta, mas simplesmente apresentando uma resposta que possibilita a tomada de consciência e transformação.

"Esse é o secreto poder do humor: capturar o modo de conhecimento do outro, fazer e dizer o que de outro modo seria indizível, e dessa maneira se apropriar do modo de conhecimento e agência do outro sem se deixar englobar por ele" (Lagrou 2007:76).

Em outra ocasião, acompanhei Niara a uma feira indígena no Parque Lage, na Zona Sul do Rio de Janeiro. Ela armou sua barraca de tapioca perto da entrada da Oca construída pelos Huni Kuins na parte externa do parque. Eu estava lá novamente como ajudante. Uma hora Niara saiu da barraca para ir assistir a seus parentes Fulni-ôs se apresentarem, muitos dos quais estavam ficando no seu apartamento na Aldeia Vertical. Em uma vez que ela saiu, eu, que já tinha ganhado autonomia para preparar as tapiocas sozinha, assumi a barraca. Um casal branco por volta dos 50 anos foi até a barraca e pediu duas tapiocas. $\mathrm{O}$ homem comentou que estava gostando muito do evento, mas estava irritado de ver que os Fulni-ô, que estavam com o corpo pintado, usavam também shorts de nylon, a maioria da marca Adidas. Assim como ele. Ele estava decepcionado e perguntou se na aldeia era assim também. Depois que Niara voltou, eu comentei o incidente com ela, que o indicou como um outro exemplo da ignorância dos brasileiros sobre os povos indígenas.

Uma outra reclamação referente à concepção dos brancos sobre os índios, como já dito, é de que todos seriam espiritualizados e 
teriam poderes de cura. Niara, ao contrário dos pajés falcatruas, dedicava grande parte da sua vida a curar as pessoas. Levava o assunto a sério e era também levada a sério por muitas pessoas que se tratavam com ela. Vi como essa reputação se espalhava em um ambiente novo quando, por causa da horta, ela começou a ir até a Prefeitura com alguma frequência. $\mathrm{O}$ prédio da Prefeitura fica bem próximo ao Morro do São Carlos e da Aldeia Vertical. Niara ia até lá não só para participar de reuniões e assinar documentos relativos à horta, mas também para pressionar as pessoas responsáveis a cumprir os prazos de entrega e as promessas de conseguir materiais como adubo, mudas e outros materiais. O setor responsável é a sala de Gerência de Produção Orgânica e Agroecológica da Secretária de Meio Ambiente, no nono andar do prédio. Ela aos poucos se tornou conhecida e querida no lugar por indicar tratamentos para as pessoas que trabalhavam ali. Um dia chegando lá, viu um dos homens sentado à sua mesa falando ao telefone com a filha: "Aquela Índia que consertou minha mão tá aqui. A da magia. Pedir pra ela me benzer? Vou pedir. Tem que dar uns presentes pra ela”. Ele brincou que ia dar muito dinheiro para ela, e Niara disse que não aceitaria de jeito nenhum e jogaria fora se ele insistisse.

Depois, um outro homem que trabalhava no mesmo escritório disse que estava com um machucado no ombro e perguntou se ela não poderia curá-lo. Depois de ouvir como ele se machucou, ela disse que sim, mas que daria trabalho. Começou a descrever um número de resguardos e tratamentos que ele deveria fazer, para mostrar que realmente dava trabalho. Todas as outras pessoas no escritório comentaram que ele era muito displicente e certamente não ia seguir as instruções à risca. Ele mesmo concordou que provavelmente não ia fazer. Ele perguntou, então, se ela não poderia fazer um feitiço. Ela disse que não funcionava assim. Ele pediu para ela esticar a mão na sua direção e falar "você tá curado". Ela fez e todo mundo riu. Eu perguntei se aquilo por acaso funcionava. Iracema e Niara falaram que não, mas que também depende de se a pessoa quer se curar. Isso iniciou uma discussão geral no escritório sobre poderes de cura e feiti- 
ços, que passou por histórias de abdução alienígena, discussões sobre a localização da glândula pineal e elogios aos médicos cubanos do programa Mais Médicos.

A brincadeira do feitiço foi demonstrativa de como as pessoas parecem achar que isso funciona. Seria um exemplo da tentativa das pessoas na cidade de querer o caminho mais fácil e esperar dos índios uma mágica. Apesar de outras pessoas no escritório terem tido experiências positivas de cura seguindo as instruções de Niara, esse homem queria o feitiço, a cura sem o trabalho. Suas instruções envolviam algumas coisas que poderiam ter sido passadas por um fisioterapeuta, como compressas frias e quentes. Mas também envolviam interdições alimentares específicas e coisas que tinham de ser feitas de acordo com a fase da lua, o que imagino que um fisioterapeuta branco dificilmente recomendaria. Niara não negava as categorias de mágica e feitiço, mas parecia querer mostrar que isso não era brincadeira. Era preciso esforço e muito rigor para cumprir as indicações do tratamento.

O preconceito com os índios na cidade viria não só dos brancos, mas também dos índios aldeados. Me contaram que os índios aldeados gostam de pedir coisas aos parentes na cidade, pois esses seriam os mais ricos e com mais acesso a bens de consumo. Essa situação seria, na verdade, muitas vezes inversa. Os índios de algumas aldeias teriam muito dinheiro, celulares melhores e televisões maiores do que os desaldeados e ainda assim pediam coisas quando na cidade.

\section{Teorias sobre a mistura}

A maneira como os meus interlocutores se identificam como indígenas e falam dos diferentes caminhos para entrar em contato e apresentar essa indianidade é complexa. No ambiente heterogêneo urbano, surgem questionamentos e situações inusitadas. A partir das situações aqui relatadas e da minha convivência com essas pessoas, tive a impressão de que, para eles, ser índio não era um estado único e estável, mas uma potencialidade que podia ser acessada. Dessa maneira, também não seria algo totalizante e inflexível. É possível ter 
um avô indígena e, apesar de outros parentes não indígenas e do que poderia ser visto como uma aparência não indígena, ainda assim ser considerado e se considerar indígena. A indianidade não parece ser algo que se dilui através do sangue ou dos costumes. Existe, sim, uma gradação, por exemplo, quando Niara fala que certa aldeia está ficando muito branca por causa da comida. Mas isso não implica a perda de uma identificação como indígena ou até da possibilidade de depois se retomar um processo de se tornar mais índio, nesse caso recuperando, por exemplo, hábitos alimentares tradicionais. Isso porque o processo de se tornar qualquer coisa, não só índio, é constante e inacabável, sempre em aberto.

A teoria das cinco gerações de Niara também mostra como a indianidade é algo que pode ser recuperado, da maneira certa - ou, pensando de outra forma, algo que pode ter sempre estado ali sem se saber. Para pensar essas maneiras de ver identidade e mistura, recupero aqui uma bibliografia desenvolvida recentemente sobre o tema.

Essas percepções não se encaixam com a ideia comum de que o povo brasileiro seria formado pela mistura das três raças, branca, negra e indígena. Essa ideia é elaborada por exemplo, por pensadores como Gilberto Freyre (1933) e Darcy Ribeiro (1996). Essa maneira de pensar leva também ao mito da igualdade racial brasileira que esconde sob um véu de suposta cordialidade uma sociedade marcadamente racista. A mestiçagem, nesta aproximação, é colocada como a inevitável (e desejável) junção de elementos diferentes para criar um novo, diferente dos anteriores. $\mathrm{O}$ povo brasileiro seria assim o resultado da mistura de três elementos de raças diferentes.

As noções apresentadas por Niara, Iracema e Dauá diferem dessa noção clássica de mestiçagem e parecem dialogar melhor com aproximações recentes à mestiçagem baseadas nas teorias etnográficas, elaboradas a partir do pensamento de povos e grupos sobre suas relações interétnicas e misturas.

Advêm da instabilidade dos corpos como expressa no perspectivismo ameríndio (Viveiros de Castro 1996) diferentes processos de 
virar Outro, do qual 'virar branco' é um caso particular. Como consta nas pesquisas de Vilaça (2000) e Kelly (2005), quando alguns indígenas, como os Wari' e os Yanomami, anunciam que estão virando brancos, essas declarações devem ser entendidas não como declarações simplistas de aculturação, mas sim a partir da própria cosmologia dos grupos. Como mostram os autores, geralmente essas declarações implicam um diferente entendimento da ideia de virar branco, que inclui a apreensão de uma nova socialidade. Parece existir recentemente uma outra face desse processo de 'virar branco', que seria o 'virar índio', casos em que populações e indivíduos passam a se identificar como indígenas.

Recentemente, existe o esforço de pensar em uma teoria etnográfica da mestiçagem, buscando se aproximar do modo como as pessoas que se estudou pensam (Goldman 2006:27). No que diz respeito à mestiçagem, Goldman sublinha que os estudos etnográficos mostram que as pessoas e coletivos pensam as relações raciais de uma maneira diferente da teoria social da miscigenação dominante. São teorias etnográficas que propõem que a junção de dois elementos diferentes não leva, necessariamente, à fusão e à criação de algo novo, mas à possibilidade da coexistência desses elementos, que é modulada de diferentes maneiras. Assim, trabalham com o operador lógico 'e', com a ideia da adição, e não de substituição ou fusão. Assim, dentre essas são comuns situações etnográficas onde povos indígenas, por exemplo, compreendem sua relação com os brancos e seu mundo como a aquisição de uma nova socialidade que não interfere ou dilui a sua socialidade indígena anterior.

Como já foi mencionado, Goldman elabora o que ele chama de teoria etnográfica da contramestiçagem um esforço teórico que busca pensar a relação entre afrodescendentes e ameríndios sem subordinar esses ao terceiro elemento branco ${ }^{4}$. A relação afro-indígena pode ser desenvolvida de três maneiras. A primeira possibilidade é aquela de coletivos que efetivamente se pensam enquanto afro-indígenas ${ }^{5}$. A segunda possibilidade é aquela em que coletivos autodenominados indí- 
genas e afrodescendentes estão em contato ${ }^{6}$. A terceira possibilidade é aquela em que o próprio antropólogo faz uma proposta afro-indígena ao proporcionar o encontro entre os materiais da etnologia ameríndia e da antropologia das religiões afro-brasileiras?.

O estudo desenvolvido por Melo (2003) em Caravelas (sul da Bahia) é sobre os seus interlocutores, que se autointitulam afro-indígenas. Assim, para as pessoas com quem Melo trabalhou o branco não é o elemento histórico determinante, pois eles enfatizam a preponderância das relações entre afro e indígenas. Além disso, para eles a mistura entre esses dois elementos não é como uma fusão que modifica os dois termos criando um terceiro, mestiço. A negação da mistura se dá em nome não de uma pureza, mas simplesmente de um modo diferente de pensar o encontro desses elementos ${ }^{8}$. Melo revela que em Carvelas a autodenominação 'afroindígena' não é uma identidade fixa "mas pode ser pensado como algo que se torna, que se transforma em outra coisa diferente do que era, mas que, de algum modo, conserva uma memória do que se foi - como um devir, portanto." (Goldman 2015a:652). Assim, o que se sugere chamar de 'contramestiçagem’ são teorias etnográficas que buscam escapar da fixidez e acompanhar o desenvolvimento das pessoas e os coletivos, privilegiando a maneira como esses pensam a si mesmos.

José Kelly traça um caminho similar a partir da Venezuela e do seu trabalho com os Yanomami, desenvolvendo a noção de antimestiçagem. Kelly ressalta que essa ideia da fusão característica do pensamento político das elites latino-americanas é a "teoria da mestiçagem entendida como fusão consumptiva das culturas, da qual resulta em um tipo novo" (Kelly 2016:32). A mestiçagem é a forma como os criollos pensam sobre si mesmos, como uma autoantropologia. Esse pensamento criollo é confrontado com as concepções indígenas sobre mestiçagem, que são outras.

Para os Yanomami com quem Kelly trabalhou durante anos, o que existe na relação com o mundo branco é a incorporação de uma nova socialidade, uma adição que não substitui ou se mistura com a 
anterior, sendo possível ser duas coisas. Essa ideia de incorporação de novas socialidades é consistente com as concepções míticas de aquisição da cultura através da imitação ou do roubo de outras criaturas (humanas ou não). É possível identificar pessoas como Yanomami ou nape em diferentes contextos, em relação a diferentes pessoas ou espaços sem que isso seja contraditório. Duas qualidades podem conviver sem se excluir ou se fundir.

Kelly também levanta outros exemplos indígenas para mostrar que o caso dos yanomami de pensar a mistura como antimestiçagem não é um caso isolado. Por exemplo, ele recupera o exemplo dos Wari' também a partir do estudo de Aparecida Vilaça, que pode ser mais aprofundado através da leitura dos trabalhos da própria autora. A partir de anos de trabalho com esse grupo de língua Txapakura, da Amazônia Meridional, Vilaça (2000) analisa o contato dos Wari' com os brancos a partir da perspectiva dos próprios indígenas. Ela analisa principalmente a declaração dos Wari' de que eles estariam virando brancos. Ao invés de entender essa afirmação como uma declaração de perda de identidade ou aculturação, analisando-a através da perspectiva do xamanismo, a autora entende que os Wari' pensam em termos de uma existência dupla, em que se tornar branco não significa que eles não sejam Wari' - da mesma maneira que o xamã é animal e humano ao mesmo tempo, sendo capaz de alternar essas duas perspectivas e acessar os dois mundos, fazendo a mediação entre eles.

"Retomemos a questão da tradição. Ao dizerem que são 'Brancos completamente', os Wari' não entendem que estão perdendo a sua tradição, ou a sua cultura, como poderíamos pensar ao vê-los beber chicha de macaxeira ou álcool, comer farinha, usar a espingarda, dançar forró. Acontece que têm agora a experiência de um outro ponto de vista. Como o xamã-onça pode ver o sangue como chicha, os Wari' sabem que a farinha de macaxeira é a pamonha dos Brancos, ou que o forró é o seu tamara" (Vilaça 2000:13).

A partir do perspectivismo ameríndio, ao modificar os corpos, os Wari' tem acesso ao mundo dos brancos, como uma nova perspectiva que, no entanto, não anula a sua anterior. Pode-se dizer que operam 
assim, com o operador lógico 'e', assim como os Yanomamis de Kelly, pensando na aquisição da socialidade branca como uma adição, e não uma substituição ou alteração da socialidade wari'. Pensando sobre a relação dos Wari' com o mundo branco e com o cristianismo, Vilaça propõe um modelo de alternância, em que esses indígenas conseguem trabalhar com diferentes perspectivas, a branca cristã e a wari', não simultaneamente, mas em diferentes contextos, sem vê-las como contraditórias ou misturadas.

"This does not mean that the Wari' perceive themselves to be on a linear path of transformation, turning white, as a result of conditions external to themselves or even by choice. They do not see themselves through the lens of culture. If there is something that characterizes them, it is the capacity to alternate, and undoubtedly the successive movements of conversion and deconversion in the past provide a clear example of this. They seem to live with this alternation with few problems, without thinking of it negatively, just as they often assert either that they are completely Wari', different from white people, or completely white (wijam, 'enemy')" (Vilaça 2016:242).

\section{Conclusão}

As teorias acima retomadas buscam pensar em uma alternativa às noções comuns de sincretismo e mestiçagem. Para pensar no encontro entre diferentes elementos, culturas, modos de vida, pessoas, coletivos, rejeitam não só a ideia de uma fusão com uma síntese, mas também cenários simplistas de uma mudança total pela aculturação ou de nenhuma mudança com uma continuidade completa pela ressignificação dos elementos exógenos. Essas teorias buscam nos seus extratos etnográficos as vicissitudes do que acontece nesses casos de encontros e contatos e a forma como diferentes grupos e pessoas lidam com a alteridade. A Aldeia Vertical e as pessoas com quem trabalhei são casos que parecem melhor pensados através dessas abordagens teóricas, que complexificam a maneira como as pessoas lidam com diferentes aprendizados e bagagens culturais. 
No que diz respeito as ideias apresentadas por Vilaça e Kelly sobre a transformabilidade dos corpos e a possibilidade de coexistência e alternância entre pontos de vista indígenas e brancos, a Aldeia Vertical parece apresentar casos específicos de pessoas que lidam com a sua indianidade de maneira similar. A noção de contramestiçagem de Goldman também é relevante, pois permite pensar a mistura como um processo constante de tornar-se, como parece ocorrer na Aldeia Vertical e a constante atualização da indianidade. Para Niara, Iracema e Dauá, a horta é o espaço privilegiado para os processos de aprendizado e transformação corporal envolvidos no acesso a sua indianidade.

Assim, para os meus interlocutores a indianidade não parece estar ligada a uma identidade fixa, mas a um processo de transformação contínuo. As pessoas podem ser índias, se tornar índias, resgatar sua indianidade. Isso não é contraditório com relação a suas declarações de ancestralidade e tradição. É uma maneira diferente de pensar sobre como acessar esses elementos. Quando fazem apontamentos sobre a indianidade dos outros, parecem estar operando a partir dessa lógica da contramestiçagem.

$\mathrm{O}$ ambiente da cidade e a aquisição de uma socialidade própria dessa, os comportamentos e vestimentas adequados etc., não parecem interferir no fato de serem índios. $O$ fato de não terem nascido na aldeia ou todos os parentes não serem indígenas também não diminui sua indianidade. Assim, a indianidade é um elemento que não se dissolve em outros, não se mistura, se mantendo através de gerações e lugares, dependendo, é claro, do interesse das pessoas em mantê-lo.

A trajetória de Niara é um exemplo desse caso. Ela fala muito sobre ter sido criada por pais e avós indígenas, em uma cidade de maioria branca onde também devia frequentar a escola dos brancos e aulas de etiqueta. Ela diz que teve que aprender a fazer as duas coisas, e a dos brancos muito bem, para não sofrer discriminação. Vem daí o seu orgulho de saber andar de salto alto melhor do que muitas mulheres brancas. Esses aprendizados se dão de forma paralela, a socialidade branca, e a socialidade indígena passada pelos pais. Ela sugere que é 
capaz de alternar entre essas e trabalhar com as duas ao mesmo tempo, como na horta, sem implicar que essas se confundam. Ela sempre indica o que foi aprendido com os pais e o que foi aprendido com os brancos, mas é capaz de trabalhar com as duas técnicas. A maneira como Niara fala parece especialmente exemplar da contramestiçagem, uma vez que ela se pensa como completamente indígena apesar de se orgulhar de dominar muito bem os hábitos dos brancos. Iracema também foi criada por brancos sem que isso interfira na sua identificação como indígena. Dauá recuperou sua indianidade através do movimento Puri apesar de ter passado anos se identificando como branco.

O humor emerge como uma força da indianidade que viabiliza as relações, tanto dentro da Aldeia Vertical quanto com as pessoas de fora. Assim, o humor é necessário para o manejo das relações. Uma das funções do humor, como caracterizado por Lagrou(2007) entre populações ameríndias, é aquele de poder apontar jocosamente excessos e comportamentos desmedidos dos tempos míticos que podem ser, então, evitados.

"Qual é o saber expresso pelo humor? O humor festivo e burlesco do ritual expressa um conhecimento de como agir sobre o mundo que os protagonistas dos mitos careciam" (Lagrou 2007:84).

Assim, talvez, o humor faça possível o conhecimento para coexistir na diferença. O Outro, acessado através do humor, é visto não como alteridade intransponível, mas como uma possibilidade do ser, e assim, experimentar o ponto de vista do Outro é se tornar mais si mesmo. Como argumentei, para as pessoas com quem trabalhei, o humor também exerce uma função central para percorrer os trajetos da vida na cidade, permitindo lidar com situações potencialmente conflituosas de discriminação, possibilitando uma forma de defesa sem recorrer a um conflito aberto.

A questão que parece permear meu trabalho de campo é a de quem, afinal, é índio. Esse parecia ser um debate interno do movimento indígena que não tinha nunca uma resposta simples. A respos- 
ta mais importante no final é a de quem tem o direito de responder à pergunta. Obviamente, só eles próprios têm o direito a essa decisão. Não cabe a antropólogos, pesquisadores ou agentes do Estado. A indianidade não é uma substância, uma identidade fixa, mas um processo constante. A ideia de virar índio não deve indicar que existe um outro lado em que o processo é acabado, em um ser estável. Como meus interlocutores apresentam, a indianidade é uma potencialidade que pode ser acessada, desde que seja feito da maneira correta, o que passa fortemente pela ideia de 'estudo' e 'aprendizado'. Busquei, assim, apontar ao longo desse artigo, algumas formas como meus interlocutores pensam sobre a questão de ser índio, se tornar índio e ser índio na cidade.

\section{Notas}

1 http://www.bbc.com/portuguese/noticias/2013/03/130322_aldeia_cq_atualiza. Acessado em 4 de janeiro de 2016, 17:50.

2 Magnani (2005) ressalta que um dos atrativos do xamanismo urbano seria a oferta de uma experiência transformadora acessivel a todos e de maneira rápida, atendendo à ânsia por soluções rápidas da sociedade moderna. Ele cita um caso de uma prática xamânica urbana que ressalta esses benefícios: "O que o budista zen busca encontrar durante trinta anos de meditação no mosteiro, o xamã consegue, em seis segundos, frente ao jaguar" (Magnani 2005:223).

3 Segundo o Dicionário Brasileiro da Língua Portuguesa Michaelis (online). Acessado em 28 de janeiro de 2017, 13:38.

4 Essa operação vinda do autor Carmelo Bene, Deleuze chama de minoração, o processo de retirar a variável majoritária de uma trama, nesse caso os brancos, para observar a relação entre os dois outros termos.

5 Esses são os casos do coletivo estudado por Cecília Melo (2003) em Caravelas no Sul da Bahia, do estudo de Rafael Santos (2010) sobre os Xakriabá, de São João das Missões em Minas Gerais, e da análise de Luiza Flores (2013) sobre a tribo carnavalesca Os Comanches, de Porto Alegre.

6 É o caso estudado por Sauma (2013), em que o coletivo Filhos do Erepecuru, de matriz afro-brasileira, traça diversas relações com povos indígenas.

7 Como é feito não só por Goldman (2014), mas também por Vanzolini, que estuda o feitiço no Xingu à luz das teorias das religiões afro-brasileiras, e de Banaggia, 
que no movimento inverso e complementar, busca observar questões afro-brasileiras a partir das teorias ameríndias.

8 Goldman também recupera o caso dos Tupinambás da Serra do Padeiro, estudados por Helen Ubinger (2012) e Daniela Alarcon (2013). Como outros indígenas do nordeste, esses já foram considerados índios misturados que estariam aos poucos perdendo sua indianidade e se tornando mestiços (Pacheco De Oliveira 1998). Os Tupinambás, no entanto, não julgam que tenham deixado de ser indígenas em momento algum, mas que tenham sido forçados a submergir para sobreviver.

\section{Referências}

BELAUNDE, Luisa Elvira. 2013. "El cachimbo Del Cocama: Una historia de alteridad y territorio en El Ucayali shipibo-konibo.” In PINEDA, R. (ed.): El aliento de la memoria Amazónica: antropología e historia de la Amazonía andina, pp. 145-167. Bogotá: IFEA \& Universidad Nacional de Colombia.

FREYRE, Gilberto. 1933. Casa Grande $\mathcal{F}$ Senzala. Rio de Janeiro: José Olímpio.

GOLDMAN, Marcio. 2015b. "'Quinhentos Anos de Contato'”: Por uma teoria etnográfica da (contra)mestiçagem”. Mana, 21(3):641-659.

. 2015a. Além da Identidade. Para uma Teoria Etnográfica da Mestiçagem. Conferência apresentada no Centro de Estudos Ameríndios da Universidade de São Paulo. . 2014. "A Relação Afroindígena”. Cadernos de Campo, 23:213-222.

2006. Como Funciona a Democracia: uma teoria etnográfica da política. Rio de Janeiro: 7 Letras.

KELLY, José Antonio. 2016. Sobre a Antimestiçagem. Curitiba: Cultura e Barbárie.

LAGROU, Els. 2007. "Rir do Poder e o Poder do Piso nas Narrativas e Performances Kaxinawa". Revista de Antropologia, 49(1):55-90.

MAGNANI, José Guilherme. 2005. "Xamãs na Cidade”. Revista da USP, 67(set/ out/no):218-227.

MALINOWSKI, Bronislaw. 1935. Coral Gardens and their Magic. London: George Allen \& Unwin Ltd.

MELLO, Cecília C. A. 2003. Obras de Arte e Conceitos: Cultura e antropologia do ponto de vista de um grupo afro-indígena do sul da Bahia. Dissertação de Mestrado. Rio de Janeiro: UFRJ-MN.

RIBEIRO, Darcy. 1996. "Sobre a Mestiçagem no Brasil". In SCHWARCZ, L. \& QUEIRÓZ, R. (eds.): Raça e Diversidade, pp. 187-211. São Paulo: EDUSP/ Estação Ciência.

VILAC̣A, Aparecida. 2000. "O que Significa Tornar-se Outro? Xamanismo e contato interétnico na Amazônia”, Revista Brasileira de Ciências Sociais, 15(44):56-72. 2016. Praying and Preying: Christianity in indigenous amazonia. University of California Press. 
VIVEIROS DE CASTRO, Eduardo. 1996. "Os Pronomes Cosmológicos e o Perspectivismo Ameríndio". Mana, 2(2):115-143.

2002. A Inconstância da Alma Selvagem e Outros Ensaios de Antropologia. São Paulo: Cosac \& Naify.

. 2014. Parecer sobre a sentença do Juiz federal José Airton de Aguiar

Portela, da Justiça federal de Primeiro Grau no Pará (Segunda Vara da

Subseção de Santarém) de 26 de novembro de 2014, relativa aos Processos 2010.39.02.000249-0 e 2091-80.2010.4.01.3902 (ações civis públicas tendo como réus a Fundação Nacional do Índio e a União).

. 2015. "O Índio Em Devir". In HERRERO, M. \& FERNANDES, U. (eds.): Baré: Povo do Rio, pp. 08-13. São Paulo: Edições Sesc.

2016. Os Involuntários da Pátria. Aula pública. Cinelândia, Rio de Janeiro, 20-04-2016.

\begin{abstract}
The paper deals with the experience of native people in the city, situations of discrimination suffered by them and the way they think about their indianity in the urban environment. Starting from ethnographic data about the experience of three native people of different origins, residents of Rio de Janeiro, we discuss how they reflect upon prejudice and the indigenous urban movement, trying to connect those with the recent theories of contramestiçagem.
\end{abstract}

Keywords: Indigenous People in the City; Indigenous Mixture; Indigenous Education; Indigenous Rio de Janeiro; Vertical Village.

Recebido em outubro de 2017. Aprovado em dezembro de 2017. 